\title{
Hubungan Persepsi Mutu Pelayanan Dengan Kepuasan Pelanggan
}

\author{
KARTIKA SARI LUBIS \\ Dosen Sekolah Tinggi Ilmu Ekonomi Riau \\ Jl. HR. Soebrantas Panam, Tuah Karya, Tampan, Kota Pekanbaru, Riau 28293 \\ kartikajq@gmail.com
}

\begin{abstract}
This study aims to determine the impact of service quality on customer satisfaction in UPT. The Environmental Health office and Laboratory Riau Province. Respondents in this study were patient in Laboratory of Dinas Kesehatan Provinsi Riau of 96 people. Based on the results of hypothesis testing using simple linear regression analysis method and processed by using SPSS program version 16.0, the results obtained that In the coefficient of determination $\left(\mathrm{R}^{2}\right)$, obtained value $\mathrm{R}=0.585$ this means the influence of independent variables (Service Quality) to the dependent variable (Customer Satisfaction) is $58.5 \%$. While the remaining $41.5 \%$ is influenced by other variables that are not included in this regression model
\end{abstract}

Keywords: Service Quality, Customer Satisfaction

UPT. Laboratorium Kesehatan dan Lingkungan Dinas Kesehatan Provinsi Riau sejak September 2006 telah menjalankan sistem mutu berdasarkan ISO/IEC 17025: 2005 yang telah menetapkan kebijakan mutu yaitu komitmen penuh secara professional dalam menerapkan sistem manajemen mutu berdasarkan ISO/IEC 17025: 2005, senantiasa mengutamakan kepuasan pelanggan, senantiasa merujuk kepada standar nasional dan internasional, seluruh personel laboratorium memahami sistem manajemen mutu berdasarkan ISO/IEC 17025:2005, bertanggung jawab secara hukum dan teknis, menjamin seluruh personel laboratorium bebas dari berbagai tekanan dari pihak manapun, mengusahakan perbaikan secara terusmenerus (UPT. Labkesling, 2011).

Implementasi sistem manajemen mutu (ISO/IEC 17025: 2005) diharapkan membuat pelayanan menjadi lebih baik, semua kegiatan dilakukan secara prosedural, terdokumentasi dan secara rutin dapat dilakukan analisis terhadap kegiatan yang telah dilakukan. Hasil pemeriksaan laboratorium digunakan untuk menetapkan diagnosa, pemberian obat dan pemantauan hasil pengobatan serta penentuan prognosis oleh karena itu hasil pemeriksaan laboratorium harus selalu terjamin mutunya (Depkes RI, 2008).
Mutu pelayanan kesehatan yang baik dapat menunjukkan pada tingkat kesempurnaan pelayanan dalam menimbulkan rasa puas pada diri setiap pelanggan. Dalam memberikan pelayanan, laboratorium menerapkan standar pelayanan yang sama, tidak membedakan antara pelanggan yang satu dan yang lain. Standar pelayanan tersebut harus dipahami dan diterapkan oleh seluruh personel laboratorium disemua tingkat organisasi laboratorium sehingga mampu memberikan pelayanan secara optimal yang akhirnya mempunyai nilai tambah bagi pelanggan.

Baik buruknya mutu pelayanan sebagaimana yang dirasakan oleh pelanggan, dapat didefinisikan sebagai persepsi atas pelayanan tersebut. Besar kecilnya kesenjangan (gap) antara harapan (ekspektasi) dengan persepsi pelanggan tentang pelayanan tersebut, akan menentukan baik buruknya penilaian atas pelayanan. Makin besar gap antara harapan dengan persepsi pelanggan terhadap pelayanan, berarti makin jauh dari rasa puas, atau dengan perkataan lain pelanggan makin kecewa. Begitu juga dengan sebaliknya.

Fenomena yang terjadi pada UPT Laboratorium Dinas Kesehatan Provinsi Riau terlihat bahwa kompetensi 
pegawainya belum optimal (Tabel 1 jenjang pendidikan dan ilmu pengetahuan dan jumlah pegawai yang melayani pasien). Kompetensi utama sebagai pelaksana layanan laboratorium yang harus memahami ilmu pengetahuan yang mendasari uji laboratorium meliputi Hematologi, Kimia Klinik, Bakteriologi, Parasitologi, Imunologi Serologi, Toksikologi, Virologi, Sitohistoteknologi dan Kimia Kesehatan. Begitu juga dengan jumlah peralatan yang digunakan, masih kurang sehingga harus ditambah lagi agar pelaksanaan pemeriksaan akan lebih cepat (Tabel 2 peralatan pada Laboratoium Dinas Kesehatan).

Fenomena lainnya berkaitan dengan keluhan dari pasien / keluarga / pengunjung yang dikumpulkan berdasarkan tanya jawab penulis pada beberapa pengunjung dan kotak saran yang ada di UPT. Laboratorium Kesehatan dan Lingkungan Dinas Kesehatan Provinsi Riau pada tahun 2015 didapatkan sejumlah 31 pucuk surat keluhan, tentang: a). Keluhan terhadap pelayanan administrasi sebanyak 23 pucuk surat, antara lain: Jadwal buka loket tidak konsisten, terlalu lama antre, pelayanan petugas terkesan kurang ramah. b). Keluhan terhadap kelengkapan sarana pelayanan sebanyak 8 pucuk surat. Jika hal ini tidak ditindak lanjuti dengan cermat oleh UPT. Laboratorium Kesehatan dan Lingkungan Dinas Kesehatan Provinsi Riau akan terus berdampak pada penurunan jumlah kunjungan bahwa pegawai atau tenaga medis paling banyak adalah berpendidikan Sekolah Menengah Analis Kesehatan berjumlah $12(19,67 \%)$ dan Sekolah Menengah Umum berjumlah 13 orang $(21,31 \%)$. Kalau dilihat dari fungsi laboratorium, yakni melakukan pemeriksaan bahan yang berasal dari manusia atau bahan bukan dari manusia yang tujuannya adalah menentukan jenis penyakit, penyebab penyakit, kondisi kesehatan dan faktor yang berpengaruh pada kesehatan perorangan atau masyarakat, maka kebutuhan tenaga medis yang terbesar adalah Analis Kesehatan sebagai tenaga teknis laboratorium. Peralatan yang ada di Laboratorium tersebut, bidang mikrobiologi sudah memenuhi syarat untuk mengidentifikasi bakteri, peralatan bidang hematologi memenuhi syarat untuk pemeriksaan hematologi lengkap dan urin lengkap, peralatan bidang serologi memenuhi syarat untuk pemeriksaan serologi lengkap dan untuk mendeteksi virus H5NI (virus flu burung yang paling membahayakan yang telah menginfeksi baik manusia ataupun hewan).

Persepsi merupakan suatu proses, dimana seseorang menyeleksi, mengorganisasikan dan menginterprestasikan stimulus ke dalam suatu gambaran dunia yang berarti dan menyeluruh. Stimulus dapat berupa sesuatu yang ditangkap oleh alat indera, seperti produk, iklan, harga, pelayanan dan lain-lain (Wulandari, 2008). Persepsi pelanggan terhadap mutu pelayanan dipengaruhi oleh harapan terhadap pelayanan yang diinginkan. Harapan ini dibentuk oleh apa yang pelanggan dengar dari mulut ke mulut, kebutuhan pelanggan, pengalaman masa lalu dan pengaruh komunikasi eksternal. Pelayanan yang diterima dari harapan yang ada mempengaruhi konsumen terhadap kualitas pelayanan (Puspita, 2009). Setiap mereka yang terlibat dalam suatu pelayanan, pasti mempunyai persepsi yang berbeda tentang unsur penting dalam menentukan mutu layanan. Perbedaan ini antara lain disebabkan oleh perbedaan latar belakang, pendidikan, pengetahuan, pekerjaan, pengalaman, lingkungan dan kepentingan.

Dalam Perencanaan tenaga medis Laboratorium perlu disadari bahwa semakin tinggi tingkat pendidikan dan kesejahteraan masyarakat, tuntutan akan pelayanan kesehatan yang berkualitas pun semakin meningkat. Sejalan dengan itu maka pelayanan diagnostik yang diselenggarakan oleh laboratorium sangat penting untuk menerapkan sebuah standar mutu yang menjamin pelayanan yang diberikan kepada masyarakat. Salah satu

p.ISSN: $2407-800 X \quad$ e.ISSN: 2541-4356 
standar mutu pelayanan di UPT Laboratorium Kesehatan dan Lingkungan Dinas Kesehatan Provinsi Riau adalah tersedianya tenaga medis dengan jumlah yang cukup dan memenuhi kualifikasi tenaga sesuai dengan jenis pelayanan laboratorium yang ada.

Berkaitan dengan mutu pelayanan, Notoatmodjo $(2012,227)$ menjelaskan ada 3 (tiga) variabel yang dapat digunakan untuk mengukur mutu, yaitu: 1). Input (struktur), ialah segala sumber daya yang diperlukan untuk melakukan pelayanan laboratorium kesehatan, seperti tenaga medis, dana, fasilitas, peralatan, bahan, teknologi, organisasi, informasi dan lainlain. Pelayanan laboratorium yang bermutu memerlukan dukungan input yang berkualitas pula. Hubungan input dengan mutu adalah dalam perencanaan dan penggerakan pelaksanaan pelayanan. 2). Proses, ialah interaksi professional antara pemberi layanan dengan konsumen (pelanggan/masyarakat). Proses ini merupakan variable penilaian mutu yang penting. 3). Output/outcome, ialah hasil pelayanan, merupakan perubahan yang terjadi pada konsumen (pelanggan/masyarakat), termasuk kepuasan dari konsumen tersebut.

Mutu pelayanan pada hakekatnya adalah tingkat kesempurnaan suatu produk atau jasa, menurut Notoatmodjo (2012: 228). Upaya peningkatan persepsi mutu pelayanan UPT Laboratorium Kesehatan dan Lingkungan Dinas Kesehatan Provinsi Riau merupakan serangkaian kegiatan yang komprehensif dan integral yang menyangkut struktur, proses dan outcome secara obyektif, sistematik dan berlanjut, memantau dan menilai mutu dan kewajaran pelayanan dengan meningkatkan efisiensi dan efektifitas pelayanan laboratorium, dan efisiensi penggunaan sumber daya yang dimiliki, dan memecahkan masalahmasalah yang terungkapkan sehingga pelayanan laboratorium yang diberikan kepada pelanggan berdaya guna dan berhasil guna. Kegiatan teknis laboratorium meliputi seluruh kegiatan pra-analitik, analitik dan pasca-analitik. Kegiatan yang berkaitan dengan administrasi meliputi pendaftaran pelanggan/specimen, pelayanan administrasi keuangan, dan pelayanan hasil pemeriksaan. Sedangkan kegiatan yang bersifat manajerial meliputi pemberdayaan sumber daya yang ada, termasuk di dalamnya adalah penata laksanaan logistic dan pemberdayaan tenaga medis.

Standar pelayanan merupakan ukuran yang telah ditentukan sebagai suatu pembakuan pelayanan yang baik. Dalam teori pelayanan publik, pelayanan bermutu dapat diwujudkan jika ada standar pelayanan minimal (SPM). SPM adalah tolok ukur yang dipergunakan sebagai pedoman penyelenggaraan pelayanan dan acuan penilaian mutu pelayanan sebagai komitmen atau janji dari penyelenggara negara kepada masyarakat untuk memberikan pelayanan yang bermutu. (http://www.unila. ac.id/ fisip-admneg/mambo-,2009).

Dalam Rancangan Undang Undang Pelayanan Publik (Republik Indonesia, 2008) standar pelayanan ini setidaknya berisi tentang: dasar hukum, persyaratan, prosedur pelayanan, waktu penyelesaian, biaya pelayanan, produk pelayanan, sarana dan prasarana, kompetensi petugas pemberi pelayanan, pengawasan intern, penanganan pengaduan, saran dan masukan dan jaminan pelayanan.

Bersandarkan pada SPM ini, seharusnya pelayanan publik yang diberikan (pelayanan bermutu) oleh birokrasi pemerintah memiliki ciri sebagaimana dirumuskan dalam kebijakan strategis melalui Keputusan Menteri Pendayagunaan Aparatur Negara (PAN) Nomor 63/Kep/M.PAN/7/2008 (Menpan, 2008) tentang Pedoman Umum Penyelenggaraaan Pelayanan Publik yang meliputi Kesederhanaan, Kejelasan, Kepastian Waktu, Akurasi, Keamanan, Tanggung Jawab, Kelengkapan Sarana dan Prasarana, Kemudahan Akses, Kedisiplinan, Kesopanan dan Keramahan serta Kenyamanan. 
Tjiptono $(2016,136)$ menyatakan, ada lima dimensi utama mutu pelayanan, yaitu: 1). Kehandalan (reliability) adalah kemampuan memberikan pelayanan dengan segera, tepat (akurat), dan memuaskan. Secara umum dimensi reliabilitas merefleksikan konsistensi dan kehandalan. Hal ini berkaitan erat dengan apakah instansi memberikan tingkat pelayanan yang sama dari waktu ke waktu dan apakah perusahaan/instansi memenuhi janjinya, membuat catatan yang akurat dan melayani secara benar. 2). Daya Tanggap (responsiveness) yaitu keinginan para karyawan membantu semua pelanggan serta berkeinginan dan melaksanakan pemberian pelayanan dengan tanggap. Dimensi ini menekankan pada sikap dari penyedia jasa yang penuh perhatian, cepat, dan tepat dalam menghadapi permintaan, pertanyaan, keluhan dan masalah dari pelanggan. 3). Jaminan (assurance) artinya karyawan/staf memiliki kompetensi, kesopanan dan dapat dipercaya, bebas dari bahaya, serta bebas dari resiko dan keraguraguan. Dimensi-dimensi ini merefleksikan kompetensi perusahaan, keramahan (sopan santun) kepada pelanggan dan keamanan operasinya. Kompetensi ini berkaitan dengan pengetahuan dan keterampilan dalam memberikan jasa. 4). Empati (Emphaty) adalah karyawan mampu menempatkan dirinya pada pelanggan, dapat berupa kemudahan dalam menjalin hubungan dan komunikasi termasuk perhatian terhadap para pelanggannya, serta dapat memahami kebutuhan dari pelanggan. Empati memungkinkan individu untuk memahami maksud orang lain, memprediksi perilaku mereka dan mengalami emosi yang dipicu oleh emosi mereka. 5). Bukti fisik atau bukti langsung (tangible), adalah ketersediaan sarana dan prasarana termasuk alat yang siap pakai serta penampilan karyawan yang menyenangkan.

Kepuasan pelanggan merupakan perasaan senang atau kecewa seseorang yang muncul setelah membandingkan antara persepsi atau kesan terhadap kinerja Jurnal Daya Saing (Vol. 4, No. 1 Feb 2018) suatu produk atau harapan-harapannya, sedangkan menurut Cote dalam Tjiptono (2016: 204), menyatakan bahwa kepuasan pelanggan merupakan evaluasi purnabeli dimana alternatif yang dipilih sekurangkurangnya sama atau melampaui harapan pelanggan, sedangkan ketidakpuasan timbul apabila hasil (outcome) tidak memenuhi harapan.

Menurut Tjiptono (2016: 255) indikator kepuasan pelanggan dapat dibedakan menjadi 6 macam, antara lain: 1). Kenyamanan pelayanan, yaitu mengupayakan terselenggaranya pelayanan yang nyaman adalah salah satu kewajiban. Kenyamanan yang dimaksud tidak hanya yang menyangkut fasilitas yang tersedia tetapi yang penting lagi sikap serta tindakan para pelaksana ketika menyelenggarakan pelayanan 2). Kebebasan melakukan pilihan, yaitu memberikan kebebasan kepada pelanggan untuk memilih serta menentukan pelayanan adalah salah satu kode etik dan kebebasan memilih pelayanan. 3). Pengetahuan dan kompetensi teknis. Prinsip pokok dalam penerapan standar pelayanan profesi, makin tinggi tingkat pengetahuan dan kompetensi teknis makin tinggi pula mutu pelayanan. 4). Efektifitas pelayanan, artinya makin efektif pelayanan tersebut, makin tinggi pula kualitas pelayanan yang diberikan kepada pelanggan. 5). Keamanan tindakan, maksudnya bagian dari kewajiban kode etik serta prinsip pokok pelayanan standar profesi. Pelayanan yang membahayakan pelanggan bukanlah pelayanan yang baik dan karena itu tidak boleh dilakukan. 6). Kepuasan seluruh pelayanan, artinya kepuasan seluruh persyaratan pelayanan yang dapat memuaskan pelanggan yang mengacu pada penerapan semua persyaratan.

Penilaian terhadap kepuasan pelanggan menjadi hal yang sangat esensial bagi setiap perusahaan atau organisasi, karena langkah tersebut dapat memberikan umpan balik (feedback) dan masukan bagi keperluan pembangunan

p.ISSN: $2407-800 X \quad$ e.ISSN: 2541-4356 
dan implementasi strategi peningkatan kepuasan pelanggan. Pada prinsipnya kepuasan pelanggan tersebut dapat diukur dengan berbagai macam metode dan teknik (Tjiptono, 2016:219), yaitu: 1). Sistem keluhan dan saran, artinya organisasi yang focus pada pelanggan (customer-centered) memberikan kesempatan yang luas kepada para pelanggannya untuk menyampaikan saran dan keluhan misalnya dengan menyediakan kotak saran, kartu komentar, customer hot lines, dan lain-lain. Informasi-informasi ini dapat memberikan ide-ide cemerlang bagi perusahaan dan memungkinkannya untuk bereaksi secara tanggap dan cepat dalam mengatasi masalah-masalah yang timbul. 2). Ghost Shopping, yaitu salah satu cara untuk memperoleh gambaran mengenai kepuasan pelanggan adalah dengan mempekerjakan beberapa orang untuk berperan atau bersikap sebagai pembeli potensial, kemudian melaporkan temuan-temuannya mengenai kekuatan dan kelemahan produk perusahaan dan pesaing berdasarkan pengalaman mereka dalam membeli produk-produk tersebut. Selain itu ghost shopping juga dapat mengamati cara penanganan setiap keluhan. 3). Lost customer analysis, artinya perusahaan seyogyanya menghubungi para pelanggan yang telah berhenti membeli atau telah pindah pemasok agar dapat memahami mengapa hal itu terjadi. Bukan hanya exit interview saja yang perlu, tetapi pemantauan customer loss rate juga penting, dimana peningkatan customer loss rate menunjukkan kegagalan perusahaan dalam memuaskan pelanggannya. 4). Survey kepuasan pelanggan, umumnya dilakukan dengan penelitian survey, baik melalui pos, telepon, maupun wawancara langsung kepada pelanggan, menaruh perhatian terhadap para pelanggannya.

Penelitian Andi Warda, etl tentang Hubungan Persepsi Mutu Pelayanan Dengan Tingkat Kepuasaan Pasien Puskesmas Perumnas di Kota Kendari, 2016, FKM Universitas Halu Oleo, menggunakan analisis data dengan dispersi data, uji korelasi spearman dan analisis faktor dengan metode varimax. Hasil penelitian menunjukkan bahwa terdapat korelasi yang bermakna antara persepsi mutu pelayanan administrasi, dokter, perawat, obat dan kelengkapan sarana dengan tingkat kepuasan pasien (p0,9, transformation matrix $0,771>0,5)$ dan faktor kedua yaitu persepsi mutu pelayanan obat dan kelengkapan sarana (rotated component matriks> 0,8, transformation matrix 0,637> 0,5), dimana faktor pertama dapat menjelaskan faktor sebesar $95 \%$. Terdapat korelasi yang positif antara kedua faktor dengan kepuasan pasien dengan kekuatan korelasi yang kuat $(>0,5)$, dimana faktor pertama (persepsi pelayanan dokter dan perawat) memiliki kekuatan korelasi yang paling besar $(0,70)$. Saran bagi puskesmas adalah agar membenahi pelayanan yang diberikan kepada pasien terutama pelayanan dokter dan perawat.

Penelitian lainnya oleh Agus Hufron, etl, 2008, Analisis Hubungan Persepsi Pasien Tentang Mutu Pelayanan Kesehatan Dengan Tingkat Kepuasan Pasien di Puskesmas Penumping Kota Surakarta, menunjukkan bahwa 1). Dari 111 pasien $37,8 \%$ menyatakan mutu pelayanan masih rendah, dan $39,6 \%$ menyatakan kepuasan pasien masih rendah. 2). Berdasarkan uji statistik membuktikan bahwa ada hubungan yang positif dan signifikan antara mutu pelayanan kesehatan dengan kepuasan pasien rawat jalan di Puskesmas Penumping Kota Surakarta. 3). Berdasarkan hasil uji multi variat ternyata sub variabel mutu pelayanan kesehatan di Puskesmas Penumping secara bersamasama memberi kontribusi sebesar 59,9\% terhadap kepuasan pasien.

\section{METODE}

Penelitian yang digunakan adalah jenis peneitian survey, dengan responden dalam penelitian ini adalah pasien di Laboratorium Dinas Kesehatan Provinsi Riau sebanyak 96 orang. Dan dikumpulkan

$$
\text { p.ISSN: 2407-800X e.ISSN: 2541-4356 }
$$


dengan menggunakan kuesioner dan diolah dengan menggunakan regresi linier sederhana dibantu program SPSS.

\section{HASIL}

Berdasarkan pengujian dari masingmasing hipotesis, maka didapatkan hasil sebagai berikut:

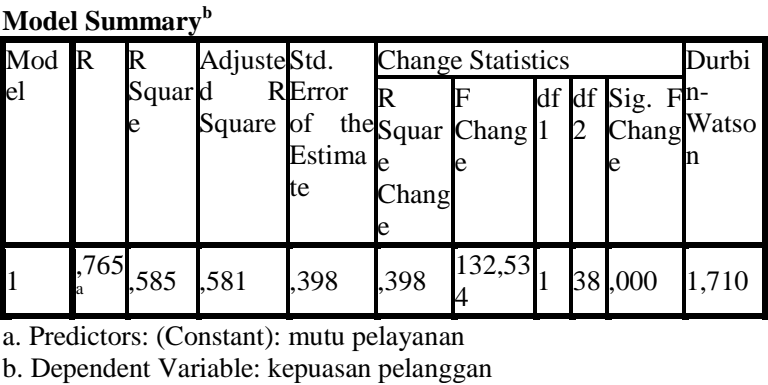

Diperoleh nilai R. Square $\left(\mathrm{R}^{2}\right)$ sebesar 0,585 ini menerangkan besarnya pengaruh varibel mutu pelayanan terhadap kepuasan pelanggan adalah sebesar 58,5\% sedangkan sisanya sebesar $41,5 \%$ dipengaruhi oleh faktor-faktor lain di luar faktor-faktor yang diteliti dalam penelitian ini.

\begin{tabular}{|c|c|c|c|c|c|c|c|}
\hline \multicolumn{8}{|c|}{ Coefficients $^{\mathrm{a}}$} \\
\hline \multirow[t]{2}{*}{ Model } & \multicolumn{2}{|c|}{$\begin{array}{l}\text { Unstandardize } \\
\text { d Coefficients }\end{array}$} & \multirow{2}{*}{\begin{tabular}{|l|} 
Standardize \\
$\mathrm{d}$ \\
Coefficients \\
Beta
\end{tabular}} & & \multirow[t]{2}{*}{ Sig } & \multicolumn{2}{|c|}{$\begin{array}{l}\text { Collinearity } \\
\text { Statistics }\end{array}$} \\
\hline & $\mathrm{B}$ & \begin{tabular}{|l} 
Std. \\
Error
\end{tabular} & & & & $e^{\text {Toleranc }}$ & VIF \\
\hline $\begin{array}{l}\text { (Constant } \\
\text { ) } \\
\text { Mutu } \\
\text { pelayanan }\end{array}$ & $\begin{array}{l}.606 \\
854\end{array}$ &, 074 &, 765 & $\begin{array}{l}2,258 \\
11,51 \\
2\end{array}$ & $\begin{array}{l}, 02 \\
6 \\
00 \\
0\end{array}$ & 1,000 & $\begin{array}{l}1,00 \\
0\end{array}$ \\
\hline
\end{tabular}

a. Dependent Variable: kepuasan pelanggan

Dengan diketahui $t_{\text {hitung }}(11,512)>$ $t_{\text {tabel }}(1,660)$ dengan sig. $(0,000)<0,05$, maka variabel independen mutu pelayanan (X) berpengaruh positif signifikan terhadap variabel dependen kepuasan pelanggan $(\mathrm{Y})$ di UPT Laboratorium Kesehatan dan Lingkungan Dinas Kesehatan Provinsi Riau.

\section{PEMBAHASAN}

Berdasarkan hasil analisis penelitian ini, bahwa persepsi mutu pelayanan pada UPT Laboratorium Kesehatan dan Lingkungan Dinas Kesehatan Provinsi Riau adalah ketersediaan tenaga medis dengan jumlah yang cukup dan memenuhi kualifikasi tenaga kerja sesuai dengan jenis pelayanan laboratorium yang ada. Kemudian daripada itu, beberapa upaya lainnya dalam peningkatan persepsi mutu pelayanan adalah berkaitan dengan fasilitas peralatan medis maupun sarana dan prasarana lainnya yang digunakan secara obyektif, sistematik dan berlanjut untuk memberikan dampak yang baik bagi terciptanya kepuasan pelanggan

\section{SIMPULAN}

Berdasarkan hasil penelitian maka dapat disimpulkan: 1). Jika dilihat dari fungsinya, menentukan jenis penyakit, penyebab penyakit, kondisi kesehatan dan faktor yang berpengaruh pada kesehatan perorangan atau masyarakat, sebaiknya UPT Laboratorium Kesehatan dan Lingkungan Dinas Kesehatan Provinsi Riau menambah kebutuhan pegawai bagian analis kesehatan dengan jumlah yang cukup dan memenuhi kualifikasi tenaga sesuai dengan jenis pelayanan laboratorium yang ada sebagai tenaga teknis di laboratorium, agar pelayanan lebih maksimal. 2). Kemudian, UPT Laboratorium Kesehatan dan Lingkungan Dinas Kesehatan Provinsi Riau juga sebaiknya lebih memperhatikan pada kepastian waktu, akurasi, keamanan, tanggung jawab, kelengkapan sarana dan prasarana, kemudahan akses, kedisiplinan, kesopanan dan keramahan serta kenyamanan, agar pelanggan mendaptkan pelayanan yang maksimal sesuai persepsi mutu pelayanan yang diberikan.

\section{DAFTAR RUJUKAN}

Ambarwati dan Diah Wulandari, 2008. Asuhan Kebidanan Nifas. Jokjakarta: Mitra Cendikia. Arikunto, Suharsimi. (2009). Manajemen Penelitian. Jakarta : Rineka Cipta

Helen Purwirtasari, 2016. Faktor-faktor yang berhubungan dengan pelayanan kesehatan bermutu di

p.ISSN: 2407-800X e.ISSN: 2541-4356 
UPT. Laboratorium Kesehatan dan Lingkungan Dinas Kesehatan Provinsi Riau. Jurnal Kesehatan Tengku Maharatu, Vol.2, No.2, Februari 2016

Hadi, 2007. Pemahaman dan Penerapan ISO/EIC 17025: 2005. Gramedia, Jakarta

Hufron, Agus etl, 2008. Analisis Hubungan Persepsi Pasien Tentang Mutu Pelayanan Kesehatan Dengan Tingkat Kepuasan Pasien di Puskesmas Penumping Kota Surakarta. Berita Ilmu Keperawatan ISSN 1979-2697, Vol . 1 No.3, September 2008:119-124

Kemenkes RI, 2013. Peraturan Menteri Kesehatan RI No. 43 Tahun 2013 tentang Cara Penyelenggaraan Laboratorium Klinik yang Baik. Kemenkes RI, Jakarta

Keputusan Menteri Pendayagunaan Aparatur Negara (PAN) Nomor 63/Kep/M.PAN/7/2008 (Menpan, 2008), Pedoman Umum Publik.

Penyelenggaraaan Pelayanan

Notoatmodjo, Soekidjo. 2012. Promosi kesehatan dan Perilaku Kesehatan. Jakarta: Rineka cipta
Setyobudi, Ismanto, 2014. Konsumen dan Pelayanan Prima. Gava media, Yogyakarta

Sugiyono, 2012. Metode Penelitian, Salemba Empat, Jakarta

Tjiptono, Fandy, 2016. Service Quality. Penerbit: Andi, Yogyakarta

UPT Labkesling, 2011. Profil UPT. Laboratorium Kesehatan dan Lingkungan Dinas Kesehatan Propnsi Riau. Pekanbaru

Warda, Andi etl, 2016. Hubungan Persepsi Mutu Pelayanan Dengan Tingkat Kepuasaan Pasien Puskesmas Perumnas di Kota Kendari, FKM Universitas Halu Oleo

(http://www.unila.ac.id/ fisip-admneg/ mambo-, 2009) 